Article

\title{
Reflecting on Education for Sustainable Development through Two Lenses: Ability Studies and Disability Studies
}

\section{Gregor Wolbring ${ }^{1, *}$ and Brigid Burke ${ }^{2}$}

1 Faculty of Medicine, Department Community Health Sciences, Community Rehabilitation and Disability Studies, University of Calgary, 3330 Hospital Drive NW, Calgary, AL T2N 4N1, Canada

2 Department of Sociology, University of Toronto, Toronto, ON M5S 2J4, Canada;

E-Mail: b.burke@mail.utoronto.ca

* Author to whom correspondence should be addressed; E-Mail: gwolbrin@ucalgary.ca; Tel.:+1-403-210-7083; Fax: 1-403-220-6494.

Received: 24 April 2013; in revised form: 6 May 2013 / Accepted: 15 May 2013 /

Published: 24 May 2013

\begin{abstract}
The call for papers asked to cast "a critical eye on the practice and purpose of sustainability-focused education, and its successes and failures, thus far". We approach this task in this paper through two lenses that have not yet been very visible in the education for sustainable development (ESD) discourse. One is the lens of disability studies which is the inquiry around the lived reality of disabled people; the other is the lens of ability studies which among others investigates (a) which abilities are seen as essential in a given context; (b) the dynamic of how an ability expectation consensus is reached, if it is reached and (c) the impact of ability expectations. We conclude that (a) no consensus has been reached within ESD discourses as to the process of how to identify essential abilities and as to a list of abilities seen as important and (b) that disabled people are invisible in the formal and informal ESD discourse. We expect the paper to be of interest to disabled people, ESD scholars, teachers of ESD in different educational settings, students of ESD training, NGOs involved in ESD as well as policy makers involved in ESD.
\end{abstract}

Keywords: ableism; ability expectation; ability studies; disability studies; disabled people; people with disabilities; education for sustainable development; sustainability 


\section{Introduction}

Increasingly, the notion takes hold that we cannot go on living as usual. Given this growing environmental insecurity, much effort has been put into promoting sustainable development. Various international documents highlight the importance of sustainable development (SD) [1]. In 2004 the United Nations General Assembly put into place a United Nations Decade of Education for Sustainable Development (DESD 2005-2014) as education is seen as an essential element for achieving sustainable development. The 2009 Bonn Declaration on Education for Sustainable Development (ESD) asserts that:

"[ESD] helps societies to address different priorities and issues inter alia water, energy, climate change, disaster and risk reduction, loss of biodiversity, food crises, health risks, social vulnerability and insecurity. It is critical for the development of new economic thinking. ESD contributes to creating resilient, healthy and sustainable societies through a systemic and integrated approach" [2].

The United Nations Educational, Scientific and Cultural Organization (UNESCO) promotes ESD for addressing current and future needs through education by harmonizing environmental, societal, cultural and economic considerations in the pursuit of an enhanced quality of life.

According to UNESCO:

"Education for Sustainable development:

- is based on the principles and values that underlie sustainable development;

- deals with the well-being of all four dimensions of sustainability-environment, society, culture and economy;

- uses a variety of pedagogical techniques that promote participatory learning and higher-order thinking skills;

- promotes lifelong learning;

- is locally relevant and culturally appropriate;

- is based on local needs, perceptions and conditions, but acknowledges that fulfilling local needs often has international effects and consequences;

- engages formal, non-formal and informal education;

- accommodates the evolving nature of the concept of sustainability;

- addresses content, taking into account context, global issues and local priorities;

- builds civil capacity for community-based decision-making, social tolerance, environmental stewardship, an adaptable workforce, and a good quality of life;

- is interdisciplinary. No single discipline can claim ESD for itself; all disciplines can contribute to ESD [sic]" [3]

If one looks at ESD through the lens of disability studies and ability studies, a few issues arise which we want to highlight in this paper.

Disability Studies is an interdisciplinary/multidisciplinary academic discipline that investigates the situation disabled people face [4,5]. It involves activists, teachers, artists, practitioners, and researchers [5]. Disability studies challenges "the view of disability as an individual deficit or defect 
that can be remedied solely through medical intervention or rehabilitation by "experts" and other service providers" and "explores models and theories that examine social, political, cultural, and economic factors that define disability and help determine personal and collective responses to difference" [5]. As disability studies scholars, we investigated two main questions with regards to ESD: are disabled people involved in the ESD discourse and what might the impact be of the ESD discourse on disabled people? We propose that disabled people are under-represented in the ESD discourse, which has an immense impact on the sustainable future of disabled people. Moreover, we are of the opinion that involving disabled people in ESD discourses is not only essential for disabled people but that disabled people have something to contribute to the ESD discourse especially within the realm of the ability expectation discourse of ESD.

Ability studies is linked to disability studies in the sense that disability studies covers people who are impacted by body related (physical, mental...) ability expectations. However, ability studies goes beyond body related ability expectations. Social entities from individuals to societies as a whole [6] cherish numerous abilities (e.g., competitiveness, ability to consume, being productive, being able to live in harmony with nature), not just body-related abilities. Ability studies scholars investigate which abilities are seen as essential in a given context, the dynamic of reaching a consensus in regards to ability expectations, and the impact of ability expectations. As ability studies scholars we asked the following questions in regards to ESD: which ability expectations are evident in the ESD discourse; has a consensus be reached in regards to ability expectations, and who are the driving forces shaping the ability expectation discourses?

Notably, no consensus has been reached within ESD discourses as to the process of how to identify essential abilities and as to (a) which abilities should be taught through ESD; (b) which abilities are needed to teach ESD and (c) which abilities are needed to learn from ESD. In our opinion, an Ability Studies lens is an important investigative tool that enables one to see barriers and opportunities for ESD.

\section{Disability Studies Lens}

Visibility of disabled/ability diverse people is one issue investigated within disability studies.

\subsection{Lack of Visibility of Disabled People within ESD}

The 2010 report Education for Sustainable Development in the UK from the UK National Commission for UNESCO describes ESD as: "ESD is fundamentally about values, with respect at the centre: respect for others, including those of present and future generations, for difference and diversity, for the environment, for the resources of the planet we inhabit" [7]. However what diversity is achieved in the ESD discourse? Of the 17,000 articles showing up in Google scholar with the keyword "education for sustainable development" less than forty articles were found when the search term "disabled people" was added and less than 60 when the search term "people with disabilities" was used. The Chair of the Monitoring and Evaluation Expert Group of the UN Decade on ESD stated in 2009, "Despite the emphasis throughout the process on participatory evaluation, feedback suggests that few stakeholders were involved with the national data collection process" [8]. She stated further that lessons learnt from the 2007-2009 were that "actors from all social sectors in learning and change for sustainable development" should be involved [8]. However according to the October 2010 report from 
Canada to United Nations Economic Commission for Europe (UNECE) and UNESCO on ESD indicators, disabled people were still invisible in the ESD discourse [9]. This invisibility is not surprising and not limited to the ESD discourse. Disabled people are also invisible in other sustainability related discourses; for example none of the World Water Reports cover disabled people [10]. As to the water discourse, one can make the case that the invisibility is due to abilities and utilities one expects stakeholders to have [11]. The invisibility in the ESD discourse is systemic, ranging from NGOs to academic institutions to governments and United Nations (UN) related agencies. Furthermore, this invisibility is rarely acknowledged. The 2010 report Education for Sustainable Development in the UK from the UK National Commission for UNESCO noticed for example the absence of a youth voice in ESD [12]; the absence of a disability voice was not mentioned. Although disabled people have not focused on the ESD discourse specifically, they have voiced their concerns for some time in regards to numerous areas that are linked to ESD such as lack of disabled people in primary education and other levels of education for that matter, and lack of involvement in disaster planning, water and climate change discourses to name a few. The UN Convention on the Rights of Persons with Disabilities [13] highlights many areas where disabled people feel disadvantaged, many of which are areas covered by SD and Millennium Development Goals (MDG). As is stated: "in many parts of the world today, lack of awareness and understanding of accessibility as a cross-cutting development issue remains an obstacle to the achievement of progress and development through the Millennium Development Goals, as well as other internationally agreed outcomes for all" [14].

Disabled people voice their discontent for not been part of the MDG process for many years [15]. The International Disability Alliance (IDA) states on their webpage that they lobbied hard to ensure the end to the invisibility and exclusion of persons with disabilities in the MDG process by including references to persons with disabilities in the outcome document of the 2010 MDG summit [16]. Indeed, disabled people are mentioned "with regards to policy and actions focusing on (1) poor people and vulnerable groups; (2) equitable access to economic opportunities and social services; (3) full and productive employment and decent work; (4) nutritional needs" [17] in the 2010 MDG outcome document. However "other themes and actions which are seen as needed for other social groups in this document do not cover disabled people: empowerment; agency of development; involvement in decision-making at all levels; inclusive financial services (particularly microfinance and access to affordable credit, savings, insurance and payments services); access to all levels education, training and vocational training (including technical, managerial and entrepreneurial training) and access to affordable and adequate public and social services; inclusion in the political and economic decision-making processes; capacity-building; multi-stakeholder dialogue with donors, civil society and the private sector to raise awareness about adequate funding and adequate housing" [17].

Furthermore, although disabled people were mentioned in the 2010 MDG outcome document the 2012 MDG report does not mention disabled people even once. Disabled people, however, are not just looking at the MDGs but are already focusing on the post-2015 development agenda. The 2011 Durban declaration of Disabled People's International (DPI) states among others: "ENSURE that disability is an intrinsic part of the Millennium Development Goals and also of all development programmes post 2015 [sic]" [18]. IDA and DPI are actively working on preventing a lack of considerations of disabled people in the Post 2015 development agenda by holding, among other 
things, global consultations. Disabled people do not only want to be involved for the sake of being involved but being invisible comes with consequences for disabled people.

To give a few examples: ESDind (Development of Indicators \& Assessment Tools for Civil Society Organization (CSO) Projects Promoting Values-based Education for Sustainable Development), a 2009-2011 research project supported by the European Commission under its Seventh Framework Programme, states on their webpage:

“The ESDind's project partners included Research Organisations (RTDs) and Civil Society Organisations (CSOs) who worked together to develop useful value-based indicators to be used in Education for Sustainable Development projects. The project design included consultation with CSO partners and a strong collaborative process. The research teams developed indicators relevant to organisations and projects, combining the on-the-ground knowledge of the CSOs with research in multiple fields, both in academic and public policy contexts" [19].

The 166 indicators generated by ESDinds are very relevant to disabled people and are full of ability expectations. Reading through them one finds various indicators (indicators 44-47) that list social groups that are worthy of attention [19]. Disabled people are not part of the listing, indicating the absence of disabled people from the project and them not having a voice in the CSOs the project collaborated with. Given the absence of disabled people, most of the indicators sound hollow and exclusionary. Indicators 42,43 and 48 for example talk about cherishing differences and the need for understanding others [19]. How can one appreciate difference if the group is missing key differences? Will such a group really be able to tackle social sustainability if disabled people are missing? Will such a group understand how environmental sustainability solution proposals might impact disabled people? We suggest that the answer to the two questions is no. These indicators are envisioned to guide ESD projects of CSO's. Indicator 67-72 are about people exploring their own ideas, visions, goals for projects and programs, identifying problems and deliver solutions [19]. If no disabled people are present the question is whether projects that might be of importance to disabled people will be chosen, whether the identification of problems relates to the problems disabled people identified and whether the solutions sought are the ones disabled people seek.

A 1998 report Education for Sustainable Development in the Schools Sector [20] identified "seven key dimensions which can be used as a framework for conceptualizing the area, namely: interdependence; citizenship and stewardship; needs and rights of future generations; diversity (cultural, social, economic, biological); quality of life, equity, and justice; carrying capacity; and uncertainty and precaution in action" [21]. The discourse in each of the areas impacts disabled people especially given that they already see themselves at a disadvantage in numerous of the listed areas. Disabled people are often not seen as citizens [22] and the need for a UN Convention on the Rights of Persons with Disabilities [13] is an indication of the lack of equity and justice disabled people experience. An interesting, less often covered aspect is what is meant with biological diversity. Does this include biological diversity intrinsic to the human species? The Convention on Biological Diversity for example does exclude humans from the concept of biological diversity impacting disabled people who are often treated not as ability diverse people but as ability deviant people.

In Sweden, the Institute for Research in ESD, in a survey, found three approaches to ESD: 
-Fact-based: inform the citizens (14\% of teachers surveyed)

-Normative: teach the values and techniques of sustainability (52\%)

-Pluralistic: engage the pupil/citizens in critical democratic debate that reflects many attitudes and encourages individual choice and action (34\%) [23].

This begs the question what is seen as facts; what values are visible in the ESD discourse and what attitudes are reflected if certain social groups such as disabled people are not present?

\subsection{The Way forward Proposal for Inclusion of Disabled People in ESD}

Section 2.1 highlight some of the MDG/sustainability discourse and ESD related problems disabled people face and the solutions they seek. However rectifying the problem is not simple. As to the MDG/Post 2015 development/sustainability discourses systemic changes are needed in how and where meetings are held (many are not physically accessible) and how information is disseminated (e.g., how much of the information is readable by blind peoples; how many videos are subtitled for deaf people; how many documents do have plain language versions so they cognitive accessible to people labelled as having a learning impairment/ability difference); data depicting the reality of disabled people has to be collected at all levels (local to global), indeed the lack of reliable data is often mentioned as one of the main problem [24] for good policy; capacity of disabled people to be able to be part of the discussions has to increase which includes finding ways to keep them up to date on current knowledge and having them contribute to the knowledge generation in a continuous fashion. Given that the funding for disability related NGOs in many places is going down, and given the lack that many disabled people have to accessing even low level of education [22,24] this is indeed a challenge. It is not good enough if a few fortunate disabled people are visible on the international/national stage. However, no long term consistent strategies seem to exist that increase the capacity of disabled people to not only be passive observers but to also be active participants in all kind of policy and other arenas. As to ESD, numerous actions should be taken first and foremost: disabled people have to be given the same quality of education (formal/informal/lifelong) as so called non-disabled people, a goal that has not been achieved as of yet [22,24-26]. Assuming that disabled people have access to the different forms of education, people who teach ESD (whether formal or informal) have to understand how the topic they teach is linked to disabled people and incorporate the disability-related context into the ESD curricula. These curricula have to cover the breath of understanding of disability and not be limited to the medical/deficiency stereotype of disabled people. Very little data unfortunately exist as to how disability is covered, if at all, in ESD curricula, although it's recognized they should be part of it [27]. One study that performed a curriculum analysis related to ESD in Iceland highlighted in one sentence that "students can deliberate the concept of equality from different points of view, such as gender equality, equality between disabled and non-disabled people, and between races" [28]. However, from the Iceland study it is not clear how the topic of equality of disabled people is taught, what the boundaries of the equality narrative in regards to disabled people are. In general there seems to be a lack of academic inquiry into the topic of ESD curricula and disabled people with Google scholar only generating 104 hits with the keyword combination "education for sustainable development" "curriculum" and "people with disabilities" and Google scholar only generating 78 hits with the keyword combination "education for sustainable development" and "curriculum" and "disabled 
people". However, no studies have really looked into what imagery of disability is actually taught within ESD curricula or whether what one is taught about disability within the ESD curricula is in opposition to teachings outside of the ESD curricula, or what the influence of the teachings about disability within ESD curricula is. We propose this to be an essential area of research, especially given the fact that the many studies covered in the disability studies for education literature highlight the problem of teaching stereotypical disability imagery and many other problems of how disability is covered in educational material [29-32]. ESD teaching is linked to citizenship education and it has to find ways to teach an appreciation for body ability related diversity to students who are to be the active citizens of the future [22]. It further has to find ways to teach skills, knowledge, attitudes and identities seen as intrinsic to active citizens to disabled people [22]. Students who see themselves as non-disabled have to appreciate that they are in an ability privileged position and have to realize that acceptance of body related ability diversity is not a passive process but demands actions on their behalf to use their body related ability privilege to improve disabled people's situation in a collaborative fashion.

\section{Ability Studies Lens}

Ability Studies is an inter/multidisciplinary field investigating how ability expectation (want stage) and ableism (need stage) hierarchies and preferences come to pass and the impact of such hierarchies and preferences [33]. The ability studies lens is linked to the disability studies lens given that body related ability expectations are a focus of disability studies. Furthermore, the disability rights movement coined the term ableism in the 1960s and 70s to highlight the disablism [34], the social discrimination, they experience due to them being perceived as being a group that is lacking "essential body related abilities" [6]. However, numerous ability expectations and forms of ableism are exhibited by social entities from individuals to societies as a whole [6]. Ability expectations and forms of ableism have changed over time and will continue to change. They lead to an ability-based and ability-justified understanding of oneself, one's body and one's relationship with others of one's species, other species and one's environment [33]. Although the cultural dynamic of ability expectations and ableism do not have to have negative consequences, certain forms of ableism have a negative track record by justifying negative "isms" such as racism, anti-environmentalism, castism, speciesism and sexism [33]. As to ESD, ability studies allow for the investigation of ability expectation dynamics evident in ESD discourses. It also allows for the investigation of how ability expectation discourses outside of ESD impact ESD discourses. As to ESD, some ability studies questions are: which ability expectations shape and continue to shape ESD curricula; what abilities are expected from teachers and students in formal, informal and lifelong learning settings; whose ability expectations are reflected in ESD; which ability expectations are in conflict with each other; what is the process evident that leads to choosing certain abilities; what ability expectation frameworks exist within the ESD discourse if any? There are various discourses that are developing ability expectation lists that are linked to ESD. To give three examples: 


\subsection{Ability Expectations Expressed in Select Discourses Relevant for ESD}

\subsubsection{Abilities Expectations Set Forth in the Human Capabilities Approach (HCA)}

The HCA was developed by Amartya Sen, Martha Nussbaum and Sudhir Anand (for many articles on this topic see [35] as a broad paradigm for evaluating the effects of social change policies on human wellbeing). HCA is seen to be useful in development issues and HCA focuses on people's ability-to-do-and-to-be. According to Landorf et al. HCA is linked to ESD as ESD is about the expansion of people's abilities-to-do-and-to-be [36]. Given Landorf et al.'s sentiment the question arising for ESD practices is which abilities-to-do-and-to-be are put forward in the HCA discourse that then ESD could endeavor to teach. To give an example of three existing ability-to-do-and-to-be lists, Amartya Sen suggested five categories of instrumental freedoms: political freedoms, economic facilities, social opportunities, transparency guarantees and protective security [36]. Martha Nussbaum generated a list of 10 essential capabilities [37], of 10 ability expectations to act upon, to have access to, to have the opportunity to obtain and Alkire and Black generated another list [38] of abilities fitting under HCA. Question is which abilities if any will be seen as useful to be taught in ESD?

\subsubsection{Abilities Expectations Set Forth in Indicator Approaches in Environmental Education and Sustainable Development}

HCA is one example of ability expectation lists developed outside of the ESD discourse that some might want to embrace for ESD purposes. However ability expectations are also evident within the ESD framework under the header of indicators (e.g., [7,39-47]) and competencies/skills (e.g., [23,39,48-50]). Rolf Jucker, director of the Swiss Foundation for Environmental Education, an independent body tasked with mainstreaming environmental education (EE) and ESD in the Swiss school system [39] lists over 25 skills (abilities), 16 values (that often ask for the ability to act on them), 12 abilities we actually should do and experience and over 37 topics of knowledge one should have the ability to learn about. The ability to generate system-wide changes in universities [51] and within societies are seen as essential for sustainable societies [39,52]. Many ESD articles highlight abilities needed by teachers, students and others in secondary (e.g., [53-57]) and higher education (e.g., [54,58-61]). One paper that links "the worlds of education for entrepreneurship and for sustainability" generated "a set of clear, distinct competencies" for monitoring "sustainable entrepreneurship development in school-based environments" [62]. Often no consensus exist as to a given ability expectation; for example, competitiveness is one ability expectation [63-68] discussed within ESD discourses [23,69-72] whereby some see it as important while others do not. Various articles claim that ESD focuses on environmental issues while ignoring social components (e.g., [73]), or that social as well as other issues are under-acknowledged in ESD [74]. On the other hand, a recent article stated that the ecocentric perspective is marginalized in current ESD debates [75]. Kopnina proposed an "Ecocentric and Anthropocentric Attitudes toward the Sustainable Development (EAATSD) scale" to make visible these two attitudes [75]. Looking at the phenomenon of ecocentric and anthropocentric attitudes from an ability studies perspective gives insight as to why a preference might exist. Both approaches have different ability expectations related to the human-nature relationship [76]. The anthropocentric school is human-centered in its interpretation of the relationship 
between humans and nature [77,78] and looks at the ability of nature to fulfill expectations of humans [76]. The eco- or biocentric school of thought is, in contrast, eco- or biosphere-centered and the ability expectation is for humans to live in harmony with the needs of the biosphere [76]. One can argue that if one exhibits certain ability expectations such as competitiveness, consumerism and GDP-ism that this predisposes one to be more anthropocentric than bio/ecocentric. That also means that if one would eliminate an anthropocentric bias within ESD one would have to eliminate certain ability expectations through ESD such as competitiveness, consumerism and GDP-ism. One would also very likely have to teach to diminish anthropocentric (human) privilege. As Bordessa states, "the removal of arguments for human privilege and the granting of moral status to nature do require the construction of a moral system that takes nature's claims for respectful treatment seriously" [79].

\subsubsection{Abilities Expectations Set Forth in the Key Competencies Approach in Sustainability} Science Education

Sustainability science (Wiek uses the term "emerging academic field focused on sustainability" to highlight that the field includes some 'non-science' disciplines [48] "seeks to understand the interactions within and between global, social, and human systems, the complex mechanisms that lead to the degradation of these systems, and the concomitant risks to human well-being and security" [80]. The discipline of sustainability science is seen as important for ESD [81]. Wiek synthesized the "laundry' list" [49] of sustainability competencies existing in the literature into an "over-arching framework of sustainability research and problem-solving competence" [49] identifying five key competencies: systems-thinking competence, anticipatory competence, normative competence, strategic competence, and interpersonal competence [49] and also entailing "analyzing the current problem constellation(s); creating and crafting sustainability visions (problem solved); exploring less desirable future scenarios that might become reality without interventions towards sustainability; developing and testing strategies to transition from the current state to sustainable states without getting deflected towards undesirable pathways (critical intervention points)" [49]. We suggest that the ability expectations and frameworks which might become established in the sustainability science arena could influence ESD educators and ESD curricula.

\subsection{The Way forward-Elements of a Framework to Generate Abilities Expectations}

Ability expectations constantly influence ESD discourses. Ability expectations evident in other discourses (e.g., HCA, disability and disabled people, industry, trade, social determinants of health, climate change mitigation and adaptation, energy security [76], sentiment around waste and footprints [82]) impact ability expectations of and within ESD. Furthermore, ability expectations change constantly; science and technology advancements are an example whereby ability expectations are impacted which in turn might impact SD and ESD discourses. Within the article "Human Engineering and Climate Change" [83] the authors proposed human engineering with the end goal of changing body abilities as a tool to fight climate change. They proposed human engineering as a safe alternative to geo-engineering because they believe change in ability expectations of humans (for example consumerism) through education is not really working; in other words, enhancement of the body is sold as an emerging solution to the worsening health of the environment. If this avenue of reasoning is 
gaining tractions one can expect a change in sentiment toward certain SD strategies such as sustainable consumption of certain products which in turn would influence what and how certain areas of ESD are taught.

Given that the very sentiment towards ability expectations is fluent, constantly evolving and multifaceted it is not surprising that different lists exist. It also seems to make sense to step back and to investigate how we come up with a list for something that we acknowledge fits ability studies scholars. Indeed, various scholars [49,84-85] are concerned with how we generate lists. Mochizuki stated: "Instead of quick "check lists" of competences, we need a democratic, deliberative and situated process of first specifying desirable competences (by asking whose needs and desires are being addressed for what purposes in what kinds of world) and then carefully articulating them in educational programmes" [84]. Robeyns highlighted five procedural issues namely explicit formulation; methodological justification; sensitivity to context; different levels of generality and exhaustion and non-reduction that she feels are needed [85]. Wiek stated that there is space for improvement in the areas of "theoretical justifications of proposed competencies, the amount of empirical evidence that these competencies enable successful, real-world sustainability research, and problem solving and follow-up studies around the specifics of the proposed competencies".

Amartya Sen stated in 2013:

"There is also a related 'social choice' problem, in determining the priorities between different kinds of freedoms, or-for that matter-even in the identification of different types of needs and the priorities between them (cf. Sen 1995, 1999b). If these identifications and priorities are to be determined by a process of democratic social choice, then there has to be freedom of discussion as well as freedom of political participation to allow the democratic process to work. Indeed, even the formation of values, including consumption behavior, may depend crucially on open public discussion; and in this sense, freedom may have some claim to priority over the identification of needs and their relative importance" [86].

To stay with the social choice problem highlighted by Sen, the ability expectations we choose whether as individual or another social structure impacts ESD discourses. We need to be clear about the ability expectation biases that drive how we define problems and solutions to the problem; for example we have to be clear whether we base our reasoning on anthropocentric or bio/eco-centric reasoning.

What we need is a taxonomy of ability expectations existing within ESD and SD discourses, the ability expectations put forward by social groups and an identification of which ability expectations are linked to which problems and solutions. This allows us to ascertain what a given proposal put forward within SD and ESD discourses can and cannot achieve and whom the given proposal can or cannot serve and whom it impacts in which way. Often, it seems that people do not have the complete picture and as such make decisions based on incomplete understanding of the problem and the consequences of a solution they adhere to. Having the taxonomy might be one tool that might allow people to make informed choices and being accountable for their choices.

So far no single list of ability expectations for the purpose of ESD exists. Some might say that one list cannot exist as demands put forward by different social groups are just too diverse. However, if that is not achievable we at least need an ability expectation impact assessment of how the different 
lists intersect and which lists benefit whom, and what the limitations are as to what and whose problems they can solve given competing ability expectations evident in different lists. We also need a working mechanism that allows us to resolve ability expectation conflicts between different social groups. Various conflict resolution mechanisms exist [87-92] as does the field of conflict studies. However, this area has not yet been systematically explored through an ability expectation lens which is needed to better understand how to ovoid and/or diminish conflicts based on diverse ability expectation views.

\section{Conclusions}

According to Kerk and Manuel, a sustainable society is a society "in which each human being has the opportunity to develop itself in freedom, within a well-balanced society and in harmony with its surroundings" [93]. According to Jucker, "a sustainable society is only possible with truly radical change, yet all our endeavours to implement ESD are within an education system and a society that show no intention of engaging seriously in this paradigm change" [39]. We propose that change is needed in the ways we deal with disabled people within the ESD discourses and in the ways we investigate and analyse ability expectations evident in SD and ESD discourses. We think that these tasks, although not simple and not open to quick fixes, have to be performed. Moreover, it is our opinion that disability studies and ability studies lenses can enrich the ESD discourse.

\section{Acknowledgments}

We thank Lucy Diep for reading an earlier version of the article.

\section{Conflict of Interest}

The authors declare no conflict of interest.

\section{References}

1. United Nation Department of Economic and Social Affairs Division for Sustainable Development (DSD). DSD: Resources-Publications-Core Publications. Available online: http://www.un.org/esa/dsd/resources/res_publcorepubli.shtml/ (accessed on 30 January 2013).

2. UNESCO. Conference on Education for Sustainable Development Bonn Declaration on Education for Sustainable Development. Available online: http:/www.esd-world-conference-2009.org/ fileadmin/download/ESD2009_BonnDeclaration080409.pdf (accessed on 30 January 2013).

3. UNESCO. Education for Sustainable Development. Available online: http://www.unesco.org/new/en/ education/themes/leading-the-international-agenda/education-for-sustainable-development/educationfor-sustainable-development/ (accessed on 30 January 2013).

4. Taylor, S.; Shoultz, B.; Walker, P. Disability Studies: Information and Resources. National Resource Center on Supported Living and Choice, Center on Human Policy, School of Education, Syracuse University. Available online: http://thechp.syr.edu/Disability_studies_2003_current.html (accessed on 30 January 2013). 
5. Society for Disability Studies. Guidelines for Disability Studies Programs Society for Disability Studies. Available online: http://disstudies.org/guidelines-for-disability-studies-programs/ (accessed on 30 January 2013).

6. Wolbring, G. Expanding ableism: Taking down the ghettoization of impact of disability studies scholars. Societies 2012, 2, 75-83.

7. UK National Commission for UNESCO. Education for Sustainable Development in the UK in 2010; UK National Commission for UNESCO: London, UK, 2010.

8. Tilbury, D. Tracking our progress. A global monitoring and evaluation framework for the UN DESD. J. Educ. Sustain. Dev. 2009, 3, 189-193.

9. Council of Ministers of Education Canada. Environment Canada; Canadian Commission for UNESCO. Report to UNECE and UNESCO on Indicators of Education for Sustainable Development: Report for Canada 2007-2010; Council of Ministers of Education, Canada Council of Ministers of Education: Ottawa, Canada, 2010.

10. Noga, J.; Wolbring, G. The economic and social benefits and the barriers of providing people with disabilities accessible clean water and sanitation. Sustainability 2012, 4, 3023-3041.

11. Wolbring, G. Water discourse, Ableismc and disabled people: What makes one part of a discourse? Eubios J. Asian Int. Bioeth. 2011, 21, 203-207.

12. Barber, R.; Boote, J.D.; Parry, G.D.; Cooper, C.L.; Yeeles, P.; Cook, S. Can the impact of public involvement on research be evaluated? A mixed methods study. Health Exp. 2011, 15, 229-241.

13. United Nations Convention on the Rights of Persons with Disabilities. Available online: http://www.un.org/disabilities/default.asp?id=150/ (accessed on 30 January 2013).

14. United Nations Enable International Day of Persons with Disabilities, 3 December 2012. Theme: Removing Barriers to Create an Inclusive and Accessible Society for All. Available online: http://www.un.org/disabilities/default.asp?id=1597/ (accessed on 30 January 2013).

15. Godziek, S. MDG 6: What about disabled people? J. Health Manag. 2009, 11, 109-126.

16. International Disability Alliance (IDA) Millennium DEvelopment Goals (MDGS). Available online: http://www.internationaldisabilityalliance.org/en/millennium-development-goals-mdgs (accessed on 30 January 2013).

17. Wolbring, G. MDGS and Disability: Bridging the Gap. In Blog of Society for International Development; Society of International Development: Rome, Italy, 2010.

18. Disabled People's International (DPI) The Durban Declaration; 8thDisabled People's International (DPI) World Assembly. Available online: http://dpi.org/DurbanDeclaration/ (accessed on 30 January 2013).

19. ESDinds. (Development of Indicators \& Assessment Tools for CSO Projects Promoting Values-based Education for Sustainable Development). Full Indicator List Developed from ESDinds Project. Available online: http://www.brighton.ac.uk/sdecu/research/esdinds/resources/ FULL\%20INDICATOR\%20LIST\%20with\%20cover.pdf (accessed on 30 January 2013).

20. Sterling Stephen and Working party of the Schools Sub-Group of the Panel for Education for Sustainable Development. for Sustainable Development in the Schools Sector: A Report to DfEE/QCA from the Panel for Education for Sustainable Development. Council for Environmental Education: Reading, UK, 1998. 
21. Summers, M.G.A. Teaching sustainable development in primary schools: An empirical study of issues for teachers. Environ. Educ. Res. 2003, 9, 327.

22. Wolbring, G. Citizenship education through an ability expectation and "Ableism" lens: The challenge of science and technology and disabled people. Educ. Sci. 2012, 2, 150-164.

23. Sahlberg, P.; Oldroyd, D. Pedagogy for economic competitiveness and sustainable development. Eur. J. Educ. 2010, 45, 280-299.

24. World Health Organization. World Report on Disability. World Health Organization (WHO). Available online: http://www.who.int/disabilities/world_report/2011/en/index.html/ (accessed on 30 January 2013).

25. Bayat, M. Understanding views of disability in the Cote d'Ivoire. Disabil. Soc. 2013, doi: 10.1080/09687599.2013.768954.

26. Yousafzai, A.K.; Dlamini, P.J.; Groce, N.; Wirz, S. Knowledge, personal risk and experiences of HIV/AIDS among people with disabilities in Swaziland. Int. J. Rehab. Res. 2004, 27, 247.

27. ACP. Ministers of Education Brussels Framework for Action on Education for Sustainable Development in ACP States. Available online: http://dev.acp-edulink.eu/sites/all/files/pagedocs/Brussels\%20Declaration\%20on\%20Education.pdf (accessed on 30 January 2013).

28. Johannesson, I.A.; Norodahl, K.; Oskarsdottir, G.; Palsdottir, A.; Petursdottir, B. Curriculum analysis and education for sustainable development in Iceland. Environ. Educ. Res. 2011, 17, 375-391.

29. Collins, K.M. A disability studies response to JTE's Themed issue on diversity and disability in teacher education. J. Teach. Educ. 2013, 64, 283-287.

30. Danforth, S.; Gabel, S.L. Vital Questions Facing Disability Studies in Education, 2nd ed.; Peter Lang Pub Inc.: New York, NY, USA, 2006.

31. Connor, D.J.; Gabel, S.L. "Cripping" the curriculum through academic activism: Working toward increasing global exchanges to reframe (Dis) ability and education. Equity Excell. Educ. 2013, 46, 100-118.

32. Moriña, A.; Cortés, M.D.; Melero, N. Inclusive curricula in Spanish higher education? Students with disabilities speak out. Disabil. Soc. 2013, doi: 10.1080/09687599.2013.769862.

33. Wolbring, G. Why NBIC? Why human performance enhancement? Innov. Eur. J. Soc. Sci. Res. 2008, 21, 25-40.

34. Miller, P.; Parker, S.; Gillinson, S. Disablism How to Tackle the Last Prejudice; Demos: London, UK, 2004.

35. Human Development and Capability Association Home. Available online: http://www.hdca.org/index.php/ (accessed on 30 January, 2013).

36. Landorf, H.; Doscher, S.; Rocco, T. Education for sustainable human development: Towards a definition. Theory Res. Educ. 2008, 6, 221-236.

37. Nussbaum, M.C. Women and Human Development: The Capabilities Approach; Cambridge University Press: Cambridge, UK, 2000.

38. Alkire, S.; Black, R. A practical reasoning theory of development ethhics: Furthering the capabilities approach. J. Int. Dev. 1997, 9, 263-279. 
39. Jucker, R. ESD between systemic change and bureaucratic obfuscation: Some reflections on environmental education and education for sustainable development in Switzerland. J. Educ. Sustain. Dev. 2011, 5, 39-60.

40. Huckle, J. Consulting the UK ESD community on an ESD indicator to recommend to Government: an insight into the micro-politics of ESD. Env. Educ. Res. 2009, 15, 1-15.

41. Tilbury, D. Rising to the challenge: Education for sustainability in Australia. Aus. J. Env. Educ. 2004, 20, 103-114.

42. O'Donoghue, R.; Lotz-Sisitka, H. Situated environmental learning in Southern Africa at the start of the UN decade of education for sustainable development. Aus. J. Env. Educ. 2006, 22, $105-113$.

43. Paden, M. Researcher-practitioner conference in Japan seeks to reorient EE to ESD and set research themes. J. Educ. Sustain. Dev. 2007, 1, 97-99.

44. Huckle, J. An analysis of new labour's policy on education for sustainable development with particular reference to socially critical approaches. Env. Educ. Res. 2008, 14, 65-75.

45. Rode, H.; Michelsen, G. Levels of indicator development for education for sustainable development. Env. Edu. Res. 2008, 14, 19-33.

46. Grabovska, R.; Grabowski, J. Implementing the United Nations decade on education for sustainable development in latvian higher education. J. Teach. Educ. Sustain. 2009, 11, 18-30.

47. Michalos, A.C.; Creech, H.; McDonald, C.; Kahlke, P.M.H. Knowledge, attitudes and behaviours. concerning education for sustainable development: Two exploratory studies. Soc. Indic. Res. 2011, 100, 391-413.

48. De Haan, G. The development of ESD-related competencies in supportive institutional frameworks. Int. Rev. Educ. 2010, 56, 315-328.

49. Wiek, A.; Withycombe, L.; Redman, C.L. Key competencies in sustainability: A reference framework for academic program development. Sustain. Sci. 2011, 6, 203-218.

50. Özdemir, O. A new environmental education perspective: "Education For sustainable development". Educ. Sci. 2007, 32, 23-39.

51. Ferrer-Balas, D.; Lozano, R.; Huisingh, D.; Buckland, H.; Ysern, P.; Zilahy, G. Going beyond the rhetoric: System-wide changes in universities for sustainable societies. J. Clean. Prod. 2010, 18, 607-610.

52. Pirages, D. Sustainability as an evolving process. Futures 1994, 26, 197-205.

53. Uitto, A.; Juuti, K.; Lavonen, J.; Byman, R.; Meisalo, V. Secondary school students' interests, attitudes and values concerning school science related to environmental issues in Finland. Env. Educ. Res. 2011, 17, 167-186.

54. Chapman, D.; Flaws, M.; le Heron, R. A due diligence report on New Zealand's educational contribution to the UN decade of education for sustainable development. J. Geogr. High. Educ. 2006, 30, 281-292.

55. Nikel, J. Making sense of education "responsibly": Findings from a study of student teachers' understanding(s) of education, sustainable development and education for sustainable development. Env. Educ. Res. 2007, 13, 545-564.

56. Qiaoling, W. Characteristics of ESD-Promoting strategies in China's basic education. J. Educ. Sustain. Dev. 2011, 5, 215-223. 
57. Lange, J.M. Education in sustainable development: How can science education contribute to the vulnerability perception? Res. Sci. Educ. 2012, 42, 109-127.

58. Juárez-Nájera, M.; Dieleman, H.; Turpin-Marion, S. Sustainability in Mexican higher education: Towards a new academic and professional culture. J. Clean. Pro. 2006, 14, 1028-1038.

59. Franz-Balsen, A.; Heinrichs, H. Managing sustainability communication on campus: Experiences from Luneburg. Int. J. Sustain. Higher Educ. 2007, 8, 431-445.

60. Fenner, R.A.; Ainger, C.M.; Cruickshank, H.J.; Guthrie, P.M. Embedding sustainable development at Cambridge university engineering department. Int. J. Sustain. High. Educ. 2005, 6, 229-241.

61. Roberts, C.; Roberts, J. Starting with the staff: How swapshops can develop ESD and empower practitioners. Env. Educ. Res. 2008, 14, 423-434.

62. Lans, T.; Blok, V.; Wesselink, R. Learning apart and together: Towards an integrated competence framework for sustainable entrepreneurship in higher education. J. Clean. Prod. 2013, doi: 10.1016/j.jclepro.2013.03.036.

63. Smither, R.D.; Houston, J.M. The nature of competitiveness: The development and validation of the competitiveness index. Educ. Psychol. Measur. 1992, 52, 407-418.

64. Trousdell, E.G. Citizenship-based competitiveness policy in a new economic world. Int. J. Public Admin. 1994, 17, 1767-1788.

65. Roessner, D.J.; Porter, A.L.; Newman, N.; Cauffiel, D. Anticipating the future high-tech competitiveness of nations: indicators for twenty-eight countries. Technol. Forecast. Soc. Change 1996, 51, 133-149.

66. Tedesco, J.C. The New Educational Pact: Education, Competitiveness and Citizenship in Modern Society; UNESCO, International Bureau of Education: Paris, France, 1997.

67. Lall, S. Competitiveness indices and developing countries: An economic evaluation of the global competitiveness report. World Dev. 2001, 29, 1501-1525.

68. World Ecomomic Forum. The Global Competitiveness Report 2011-2012 World Ecomomic Forum. Available online: http://www3.weforum.org/docs/WEF_GCR_Report_2011-12.pdf (accessed on 30 January 2013).

69. Onis, Z. The limits of neoliberalism: Toward a reformulation of development theory. J. Econ. Issues 1995, 29, 97-119.

70. Sonntag, V. Sustainability-in light of competitiveness. Ecol. Econ. 2000, 34, 101-113.

71. Wüstenhagen, R. Sustainability and competitiveness in the renewable energy sector. Greener Management International 2003, 44, 105.

72. International Institute for Sustainable Development (IISD). Climate Change and Competitiveness A Survey of the Issues; IISD: Winnipeg, Canada, 2005.

73. Iyengar, R.M. After the Smoke Clears: Toward Education for Sustainable Development in Bhopal, India. Comp. Educ. Rev. 2011, 55, 424-456.

74. Summers, M.; Childs, A. Student science teachers' conceptions of sustainable development: An empirical study of three postgraduate training cohorts. Res. Sci. Technol. Educ. 2007, 25, 307-327.

75. Kopnina, H. Evaluating education for sustainable development (ESD): Using ecocentric and anthropocentric attitudes toward the sustainable development (EAATSD) scale. Env. Dev. Sustain. 2012, 15, 607-623. 
76. Wolbring, G. Ableism and energy security and insecurity. Stud. Ethics Law Tech. 2011, 5, Article 3.

77. Stanford Encyclopedia of Philosophy. Environmental Ethics Stanford Encyclopedia of Philosophy. Available online: http://plato.stanford.edu/entries/ethics-environmental/\#EarDevEnvEth/ (accessed on 30 January 2013).

78. Verhagen, F.C. Worldviews and metaphors in the human-nature relationship: An ecolinguistic exploration through the ages. Language Ecology 2008, 2, 1-18.

79. Bordessa, R. Geography, postmodernism, and environmental concern. Canadian Geographer/Le Géographe canadien 1993, 37, 147-156.

80. Steinfeld, J.I.; Mino, T. Education for sustainable development: The challenge of trans-disciplinarity. Sustain. Sci. 2009, 4, 1-2.

81. Paraschivescu, A.; Bontas, D.; Radu, C.E.; Caprioara, M.F. The Sustainability Science: Challenge for an Education for Sustainable Development. In Proceedings of the 5th WSEAS International Conference on Waste Management, Water pollution, Air pollution, Indoor climate (WWAI'11), Iasi, Romania, 1-3 July 2011; pp. 105-110.

82. Wolbring, G.; Leopatra, V.; Noga, J. The sentiment of waste and the measure of footprints evaluated through an ableism lens. Eubios. J. Asian Int. Bioeth. 2012, 22, 117-123.

83. Liao, S.M.; Sandberg, A.; Roache, R. Human engineering and climate change. Ethics Pol. Environ. 2012, 15, 206-221.

84. Mochizuki, Y.; Fadeeva, Z. Competences for sustainable development and sustainability: Significance and challenges for ESD. Int. J. Sustain. High. Educ. 2010, 11, 391-403.

85. Robeyns, I. Sen's capability approach and gender inequality: Selecting relevant capabilities. Femin. Econ. 2003, 9, 61-92.

86. Sen, A. The ends and means of sustainability. J. Hum. Dev. Capabil. 2013, 14, 6-20.

87. Dennis, J.D.S. Paradigms, theories, and metaphors in conflict and conflict resolution: Coherence or confusion? In Conflict Resolution Theory and Practice; Dennis J.D.S., van der Merwe, H., Eds.; Manchester University Press: Manchester, UK, 1993; pp. 3-24.

88. Bonta, B.D. Conflict resolution among peaceful societies: The culture of peacefulness. J. Peace Res. 1996, 33, 403-420.

89. Borel, R.; Cawagas, V.; Jimenez, A.; Salvetti, N. Education for sustainable development at the university for peace. J. Edu. Sustain. Dev. 2011, 5, 245-249.

90. Candice, C. Conflict Resolution and Peace Education: Transformations across Disciplines; Palgrave Macmillan: New York, NY, USA, 2012.

91. You Can Canada. Available online: http://www.youcan.ca/national/about/overview/ (accessed on 30 January 2013).

92. Ramsbotham, O.; Miall, H.; Woodhouse, T., Eds. Contemporary Conflict Resolution; Polity/Wiley: Mississauga, Canada, 2011.

93. Van de Kerk, G.; Manuel, A.R. A comprehensive index for a sustainable society: The SSI-the sustainable society index. Ecol. Econ. 2008, 66, 228-242.

(C) 2013 by the authors; licensee MDPI, Basel, Switzerland. This article is an open access article distributed under the terms and conditions of the Creative Commons Attribution license (http://creativecommons.org/licenses/by/3.0/). 